\title{
BUSINESS STRATEGY DEVELOPMENT OF LANGUAGE SERVICE PROVIDER IN THE COVID-19 ERA
}

\author{
Yanti Susanti $^{1, \square)}$, Muhammad Imam Nashiruddin ${ }^{2)}$ \\ ${ }^{1}$ Nathan Associates Inc, DKI Jakarta. \\ ${ }^{2}$ Telkom University, Bandung, West Java. \\ ${ }^{\unrhd_{e-m a i l}}$ :1ysusanti@nathaninc.com;imamnashir@telkomuniversity.ac.id
}

\begin{abstract}
COVID-19 pandemic era stimulates a more competitive environment in the business of the language industry. Appropriate business strategy development to respond and to determine business direction become crucial for language service providers. The qualitative descriptive methodology applied to this study, and data for analysis was collected through interviews with the owner and CEO of Cakrawala Translation Service - one of the language service providers in Indonesia, which was established in 2000. Further analysis was conducted on the language industry micro and macro environment, key success factors of the industry, and business core competence. The strategy formulation was carried out through TOWS (Threat, Opportunity, Weakness, and Strength) matrix analysis. Results of the analysis shown Cakrawala Translation Service has several business strategy alternatives, which makes it possible to implement in order to embrace current and future business competition in the language industry. The business strategy alternatives are marketing penetration, updated technology, and uniqueness of service. The study results can be used to provide recommendations for language service providers to develop their business strategy in the COVID-19 pandemic era.
\end{abstract}

Keywords: COVID-19, language, competitive, business, strategy

\begin{abstract}
ABSTRAK
Era pandemi COVID-19 menstimulasi lingkungan bisnis yang lebih kompetitif dalam industri bahasa. Pengembangan strategi bisnis yang tepat untuk merespon dan menentukan arah bisnis menjadi penting bagi para penyedia layanan bahasa. Metodologi deskriptif kualitatif diterapkan dalam studi ini, dan data yang dianalisis dikumpulkan melalui wawancara dengan pemilik dan CEO Cakrawala Translation Service - salah satu penyedia layanan bahasa yang berdiri sejak tahun 2000. Analisis lebih lanjut dilakukan pada lingkungan mikro dan makro industri bahasa, faktor-faktor kunci agar sukses di industri ini, dan kompetensi utama dalam bisnis tersebut. Hasil analisis menunjukkan bahwa Cakrawala Translation Service memiliki beberapa alternatif strategi bisnis yang yang mungkin untuk diterapkan demi menghadapi kompetisi saat ini maupun di masa mendatang dalam industri bahasa. Strategi bisnis tersebut adalah penetrasi pasar, penggunaan teknologi terkini, dan pemberian layanan yang unik. Hasil studi ini dapat dipakai sebagai rekomendasi bagi penyedia layanan bahasa untuk membuat strategi bisnis mereka di era pandemic COVID-19.
\end{abstract}

Kata kunci: COVID-19, bahasa, kompetitif, bisnis, strategi

\section{INTRODUCTION}

Covid-19 pandemic era stimulates a more competitive environment in the business of the language industry. The situation affected translators, interpreters, language service providers, professional associates, etc. Stakeholders in the industry should adjust their mechanism to operate the business or respond to current conditions. Not all of them are ready and know how to respond, thus making them at high risk of failure to survive.

Appropriate business strategy development to respond and to determine business direction become crucial for language service providers. Analysis of internal and external environment of the industry will enable language service providers to better understand the business core competence, identify better 
strategy formulation and choose relevant and implementable strategies.

Porter in 1980 defined competitive advantage as the capability of a company to produce value for consumers at prices lower than production costs or consumers are willing to pay premium prices because the value of these products is considered higher than the price.

A company is considered successful in achieving a competitive advantage if it can obtain profits above the average industry profits (Walker \& Madsen, 2016). (Wiggins \& Ruefli, 2002) moreover, agree if profits above the average industry profits were achieved for ten years at the minimum. On the other hand, several opinions state that competitive advantage is defined if the company succeeds in obtaining profit that is above normal or breakeven level (Peteraf, 2007).

Wheelen et al. (2018) define business strategy as a decision to focus on the competitive position of the company's products/services in the industry or specific market segments that the company serves. If the corporate strategy provides direction in developing, stabilizing, and shrinking business owned by the company, the business strategy addresses how companies and business units compete with similar companies in the industry.

Business strategies are policies and guidelines that determine how a company competes in industry and specific ways to form a competitive advantage (Grant, 1991).

\section{RESEARCH METHOD}

Qualitative research methodology applied, and data for analysis was collected through in-depth interview with the owner and CEO of Cakrawala Translation Service. Further analysis was conducted on the language industry micro and macro environment, key success factors of the industry, and business core competence. The strategy formulation was carried out through TOWS (Threat, Opportunity, Weakness, and Strength) matrix analysis.

\section{RESULT AND DISCUSSION}

Key success factors of the industry including the internal core competence analysis are quality work, affordable price, application of the latest technology, fast response to clients' needs, and human capital competence of the language provider. These factors may contribute to the success of a language service provider. Meanwhile, every language service provider should have a competitive advantage to distinguish them with other providers and to help it survive in the industry and surpassing its competitors.

In depth-interviews with the CEO gave the opportunity to capture rich, descriptive data and unfolding complex things in operational aspects of the business. Further analysis using TOWS matrix shows a combination of strategies for the following aspects:

a. SO (strengths - opportunities) Strategies

SO1. Improving human resources' competence in producing quality translation results.

SO2. Extend local and global market share.

b. ST (strengths - threats) Strategies

ST1. Exposure of uniqueness of Cakrawala's services to new potential clients.

ST2. Customize customer-oriented service.

c. WO (weaknesses - opportunities) Strategies.

WO1. Maintain or establish collaboration with other translation agencies. WO2. Application of technology that increases translation productivity. 
WO3. Developing better marketing strategy.

d. WT (weaknesses - threats) Strategies

WT1. Expand network with a reliable business partner.

WT2. Application of a comprehensive Translation Management System.

WT3. Maintain excellent compensation and benefit for Cakrawala's translators.

A comprehensive review of all potentials for improving the competitive advantage of this language provider is crucial. All of these will enable the organization to select and define key strengths to strive in the industry.

TOWS matrix analysis was used as a foundation to conduct more advanced analysis to measure the pros and cons of the strategy options. The selected strategies to implement are as follows:

a. Improving and maintaining translators' competence on health-related subjects (Market Penetration).

b. Application of technology that increase translation productivity (Updated Technology).

c. Exposure of uniqueness of Cakrawala services to new potential clients (Uniqueness).

d. Application of Translation Management System (Updated Technology).

Strategy options shall become valuable inputs for Cakrawala Translation Service to define future plan to improve its management in business operations, marketing, financial, and human resources.

The study results can also be used to provide recommendations for language service providers to develop their business strategy in the COVID-19 pandemic era.

\section{CONCLUSION}

Several business strategy alternatives are possible to implement in order to embrace current and future business competition in the language industry.
The business strategy alternatives of the Cakrawala Translation Service are marketing penetration, updated technology, and uniqueness of services.

\section{Acknowledgment}

The authors expressed appreciation to the University of Prof DR. Moestopo (Beragama) and its faculty member for their support to this research.

\section{REFERENCES}

[1] Nashiruddin, M. I., 2018. The Strategic Management Worksheet. University of Prof DR. Moestopo (Beragama). Jakarta.

[2] Nashiruddin, M. I., 2019. The Business Strategy Module. University of Prof DR. Moestopo (Beragama). Jakarta.

[3] Peteraf, M., 2007. The ResourceBased Theory of The Firm Challenges, New And Old. International. Journal of Learning and Intellectual Capital, 4(January 2007), 1-10.

[4] Porter, M. E., 1980. Competitive Strategy: Techniques for AnalyzingIndustries and Competitors. The Free Press (First Edition). New York: The Free Press.

[5] Walker, G., \& Madsen, T. L., 2016. Modern Competitive Strategy. McGraw-Hill Education (4th Edition). McGraw-Hill Education.

[6] Wheelen, T. L., Hunger, J. D., Hoffman, A. N., \& Bamford, C. E., 2018. Strategic Management and Business Policy: Globalization, Innovation, and Sustainability (15th ed.). Pearson.

[7] Wiggins, R. R., \& Ruefli, T. W., 2002. Sustained Competitive Advantage: Temporal Dynamics and the Incidence and Persistence of Superior Economic Performance. Organization Science, 13(1), 81-105. 
